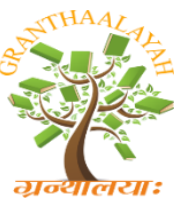

INTERNATIONAL JOURNAL OF RESEARCH GRANTHAALAYAH A knowledge Repository

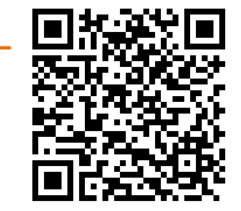

Science

\title{
PHYTOCHEMICAL SCREENING, GC-MS AND FT-IR ANALYSIS OF METHANOLIC EXTRACT LEAVES OF ELETTARIA CARDAMOMUM
}

\author{
Poonam Khatri $^{* 1}$, J.S. Rana ${ }^{2}$, Pragati Jamdagni ${ }^{3}$, Anil Sindhu ${ }^{4}$ \\ *1, 2, 3,4 Department of Biotechnology, Deenbandhu Chhotu Ram University of Science and \\ Technology, Murthal- 131039, Sonipat, Haryana, India
}

DOI: https://doi.org/10.29121/granthaalayah.v5.i2.2017.1726

\begin{abstract}
In this modern era, medicinal plants are at great attention to the researchers as most of the drug industries depend on medicinal plants for the production of therapeutic compounds. In many countries especially in India, plants are the conventional source of pharmaceutical biochemical, food colours, flavours and fragrances. Hence, the main aim of the study was the identification of bioactive compounds from the leaves of Elettaria cardamomum by Gas Chromatography and Mass spectroscopy (GC-MS). The GC-MS study revealed the presence of various compounds like Vitamin E, Squalene, Eucalyptol, Stigmast-5-en-3-ol, 4H-1-Benjopyran-4-one, 2,3-dihydro5, 7-dihydroxy-2-pheny, Octadecanoic acid, Phytol, Hexadecanoic acid in the methanolic extract of Elettaria cardamomum. Henceforth, the Elettaria cardamomum may have chemo preventive, antidiabetic, anti- microbial and anticancer activity due to the presence of secondary metabolites in the methanolic extract. The results of FTIR analysis confirmed the presence of alcohol, phenols, alkanes, alkyl halides and alkynes. In the present study, leaf sample of this plant was analyzed for the first time. This work will help to identify the active components, which may be used for therapeutic purposes. This study offers a platform of using Elettaria cardamomum leaves as herbal alternative for many diseases.
\end{abstract}

Keywords: Methanol Extract; Phytochemical; Elettaria Cardamomum; GC MS And FTIR.

Cite This Article: Poonam Khatri, J.S. Rana, Pragati Jamdagni, and Anil Sindhu. (2017). "PHYTOCHEMICAL SCREENING, GC-MS AND FT-IR ANALYSIS OF METHANOLIC EXTRACT LEAVES OF ELETTARIA CARDAMOMUM.” International Journal of Research Granthaalayah, 5(2), 213-224. https://doi.org/10.29121/granthaalayah.v5.i2.2017.1726.

\section{Introduction}

Traditional medicine is the entirety of knowledge, skills and study based on the beliefs, theories and experiences indigenous to different cultures that are used to prevent and diagnose physical and mental illness. For millions of years, herbal remedies have healed the sick and passed on to next generation (WHO). The World Health Organization has been encouraging countries to 
identify and exploit traditional medicine since 1980. The Indian traditional system of medicine namely Ayurveda and Siddha emphases the use of plant based medicines and treatments (Kirtikar et al., 1918). Everyday new diseases are being identified due to our disruptive life style, but the fact is that our nature contains cure for all diseases and potentially worthy treasures in medicinal plants are still unknown. It is estimated that almost $25 \%$ of prescribed medicines contain plant extracts or active compounds produced from plants. For examples - aspirin (analgesic), vinblastine and paclitaxel (anticancer agents) exclusively derived from plant sources (Pankaj et al., 2011). By keeping in mind the scope of medicinal plants we should spend some more time and resources in developing new medicines.

Elettaria cardamomum (Zingiberaceae) or cardamom is commonly known as queen of spices for the versatile use in cooking practice. Cardamom is a perennial shrub with fleshy, thick and lateral roots and the plant grows to a height of eight feet (Kapoor, 2000). It is native to South Asia but it is commercially cultivated in Sri Lanka, Tanzania, Morocco, Guatemala and Southern India (El-Malti et al., 2007).

Cardamom has antifungal, antibacterial (Agaoglu et al., 2005; Bansod and Rai, 2008; Singh et al., 2009), antioxidant (Singh et al., 2009; Lin et al., 2009; Sultana et al., 2010), gastro protective effect (Jamal et al., 2006) and anticancer properties (Sengupta et al., 2005).

Cardamom oil is used in perfumery, food and in medicine which is used as a powerful antiseptic, stimulant, expectorant, aromatic, carminative, stomachic, diuretic and anti-spasmodic (Baytop, 1984; Korikontimath et al., 1999). In Saudi Arabia and the Near East, Cardamom is used largely in the preparation of "Gahwa" a strong cardamom coffee concoction (Baytop, 1984).

Within an era, there are a number of advances in analytic techniques including Gas Chromatography-Mass Spectroscopy (GC- MS) and Fourier Transform Infrared spectroscopy (FTIR) that are used for identification and determination of phytochemical compounds (Roberts and Xia, 1995). GC- MS is a very compatible and the most commonly used technique for the identification and quantification purpose. FTIR is the most powerful tool for identifying the functional groups present in compounds (Ronald, 1997). The presented study is carried out on the bioactive compounds present in the Elettaria cardamomum leaves by the use of GC-MS and FT-IR techniques.

\section{Materials and Methods}

\subsection{Plant Material}

The medicinal plant used for the study were collected from Ch. Devi Lal Herbal Nature Park Chuharpur, Yamunanagar (Haryana) and maintained in the University nursery.

\subsection{Preparation of the Extract}

The fresh and healthy cardamom leaves were washed 2-3 times with running water and then air dried under shade. Afterwards, the dried leaves were grinded with mechanical grinder and the powder was kept in small-labeled plastic bags. $100 \mathrm{~g}$ of leaves of cardamom were subjected to 
successive extraction with methanol solvent using Soxhlet apparatus. The solvent were evaporated under reduced pressure and stored in desiccators at $4{ }^{\circ} \mathrm{C}$. The methanol extract was used for GC-MS and FTIR analysis.

\subsection{Phytochemical Screening}

Phytochemical analysis was carried out for identification of terpenoids, flavonoid, tannins, phenols, phytosterols, alkaloids and saponins according to standard methods (Kumar et al., 2007).

\subsubsection{Test for Saponins}

a) Foam test- $1 \mathrm{~mL}$ solution of extract was diluted with distilled water to $20 \mathrm{~mL}$ and shaken for $15 \mathrm{~min}$. Development of stable foam confirms the presence of saponins.

b) $1 \mathrm{~mL}$ extract was treated with $1 \%$ lead acetate solution and formation of white precipitates suggests the presence of saponins.

\subsubsection{Test for Tannins and Phenols}

The test extract was taken in water, warmed and filtered. $5 \mathrm{~mL}$ of filtrate was allowed to react with $1 \mathrm{~mL}$ of $5 \%$ ferric chloride solution. Dark green or deep blue color shows the presence of tannins and phenols.

\subsubsection{Test for Amino acids and Proteins}

Small quantity of the extract was dissolved in minimum quantity of water and filtered. Filtrate was subjected to Millons test and Biuret test.

\subsubsection{Test for Sugars}

Small quantity of extract was dissolved in $4 \mathrm{~mL}$ of distilled water and filtered and the filtrate was subjected to Molisch's test and Iodine Test.

\subsubsection{Test for Glycosides and Sterols}

Salkowaski test- $10 \mathrm{mg}$ of extract was dissolved in $2 \mathrm{~mL}$ of chloroform and $2 \mathrm{~mL}$ of concentrated sulphuric acid was added from the side of the test tube. Test tube was shaken for few minutes and the development of red color in chloroform layer indicated the presence of glycosides and sterols.

\subsubsection{Test for Alkaloids}

Mayer's test- 2-3 mL filtrate when mixed with a few drops of Mayer's reagent results in formation of precipitate (Shankar et al., 2014). 


\subsubsection{Test for flavonoids}

Shinoda test- The extracts were dissolved in alcohol. One piece of magnesium followed by concentrated hydrochloric acid was added drop wise and heated. Appearance of magenta color confirms the presence of flavonoids (Shankar et al., 2014).

\subsubsection{Test for Terpenoids}

About $0.5 \mathrm{~g}$ plant extract in separate test tubes was taken with $2 \mathrm{~mL}$ of chloroform and concentrated sulphuric acid was added carefully to form a layer. Observation for presence of reddish brown color at interface was recorded to show positive results for the presence of terpenoids (Venkatesan et al., 2009).

\subsection{GC-MS Analysis}

Methanol extract of Elettaria cardamomum leaves was analyzed with the help of GC-MS analyzer (GCMS-QP2010 Plus). Helium was used as carrier gas at a constant flow of 1.2 $\mathrm{mL} / \mathrm{min}$, an injection volume of $2.0 \mu \mathrm{L}$, injector temperature $260.0{ }^{\circ} \mathrm{C}$ and ion- source temperature $230.0{ }^{\circ} \mathrm{C}$ was employed. The oven temperature was operated according to the following mode: $100{ }^{\circ} \mathrm{C}$ held for $1 \mathrm{~min}$, rising at the rate of $10{ }^{\circ} \mathrm{C}$ per min up to $250{ }^{\circ} \mathrm{C}$ with 6 min hold, rising at the rate of $15^{\circ} \mathrm{C}$ per min upto $300{ }^{\circ} \mathrm{C}$ with 20 min hold up. The total GC-MS running time was about 46 min.

\subsection{Identification of Components}

Identification was based on molecular mass, molecular structure and calculated fragments. Interpretation of mass spectrum GC-MS was done using the database of National Institute Standard and Technique (NIST) having more than 62,000 patterns. The spectrum of the unknown component was compared with the spectrum of the known components stored in the WILEY library. Compound name, molecular weight, retention time, percentage and structure of various components of the test materials were ascertained.

\subsection{FTIR Spectroscopic Analysis}

FTIR analysis was performed using Perkin Elmer spectrophotometer system, which was used to detect the characteristic peaks and their functional groups using ATR (Attenuated Total Reflectance) accessory. The IR scan was performed in the wave number region of $4000-550 \mathrm{~cm}^{-1}$ (mid- infrared range).

\section{Results and Discussion}

Phytochemical compounds such as flavonoids, tannins, aromatic compounds or secondary metabolites act as defense mechanism against many microorganisms. The therapeutic properties of medicinal plants are perhaps due to the presence of various secondary metabolites such as flavonoids, alkaloids, tannins, saponins, phytosterols and phenolic compounds (Britto and Sebastian, 2012). The presence of flavonoids, alkaloids, saponins, alkaloids, phenolic 
compounds, phytosterols, and terpenoids are used in antiplasmodic, analgesic and bactericidal activities (Stary, 1998). Results for preliminary phytochemical screening of the Elettaria cardamomum methanol extract is given in the Table 1 .

Table 1: Preliminary phytochemical screening of Elettaria cardamomum methanol extract

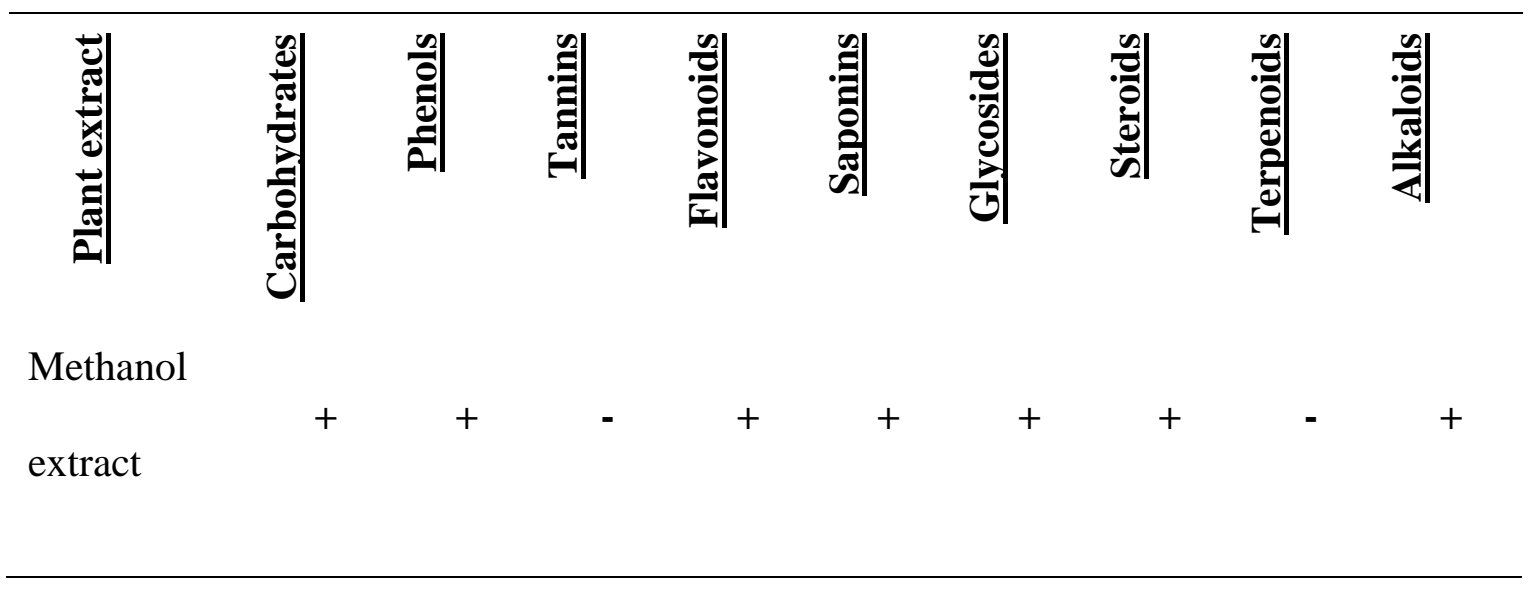

$(+)=$ Positive (present); $(-)=$ Negative $($ absent $)$

The components present in the methanol extract of Elettaria cardamomum were identified by GC-MS analysis (Figure 1). The active compounds with their retention time (RT), molecular formula and molecular weight (MW) in the methanol extract of leaves of Elettaria cardamomum re-presented in Table 2. Twenty-two compounds were identified in methanol extract of leaves of Elettaria cardamomum.

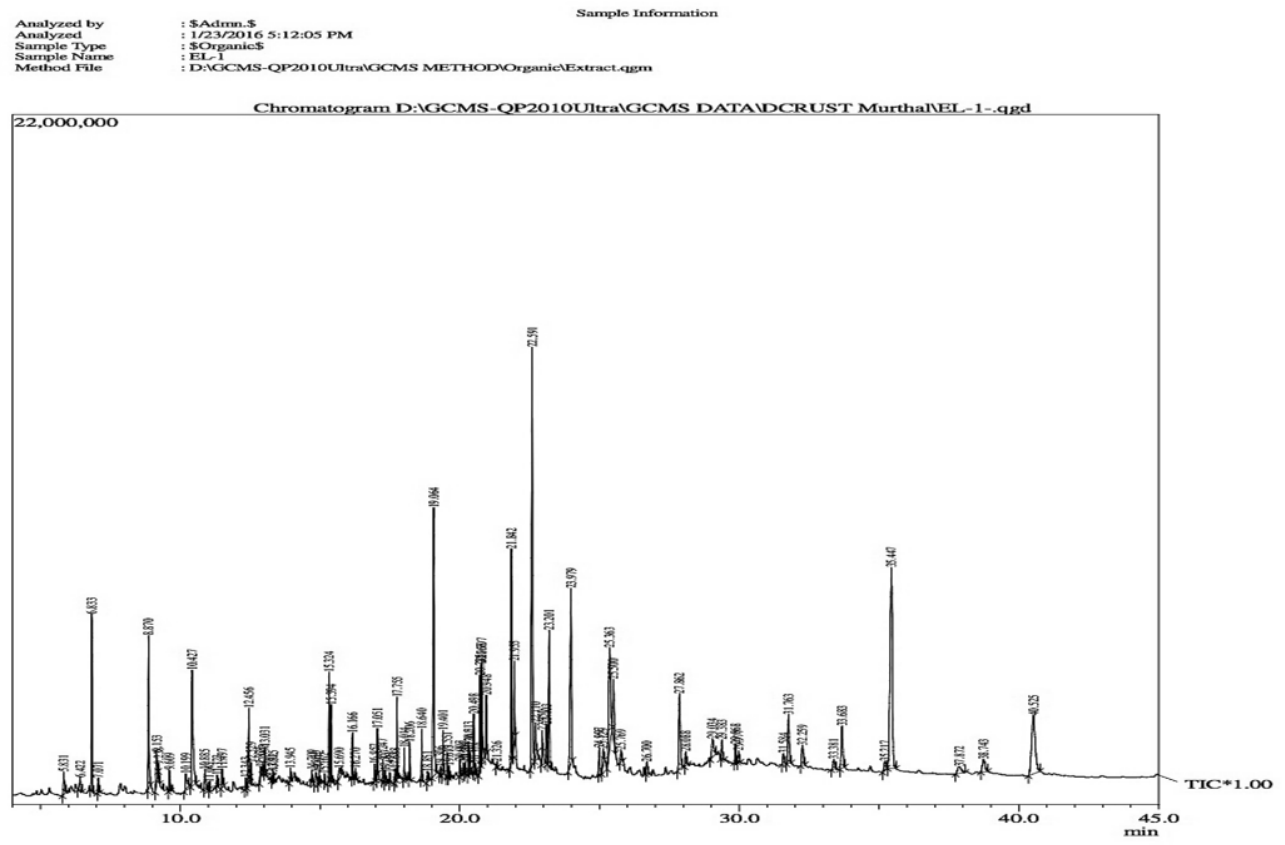

Figure 1: GC-MS chromatogram of the methanolic extract of Elettaria cardamomum leaves 
Table 2: GC-MS analysis of phytocompounds identified in the methanolic leaves extract of Elettaria cardamomum

\begin{tabular}{|c|c|c|c|c|}
\hline$\underline{\text { Peak }}$ & $\underline{\text { R.Time }}$ & Peak Area & $\underline{\text { Area\% }}$ & $\underline{\text { Name }}$ \\
\hline 1 & 5.831 & 2245644 & 0.60 & Bicyclo [3.1.1] heptane, 6,6-dimethyl-2-methyl \\
\hline 2 & 6.422 & 1293890 & 0.35 & 3-Hexenoic acid, (E)- \\
\hline 3 & 6.833 & 11227585 & 3.01 & Eucalyptol \\
\hline 4 & 7.071 & 1015506 & 0.27 & Benzene acetaldehyde \\
\hline 5 & 8.870 & 9882210 & 2.65 & Bicyclo [2.2.1] heptan-2-one, 1,7,7-trimethyl-, (1s)- \\
\hline 6 & 9.153 & 3215177 & 0.86 & Benzenepropanal \\
\hline 7 & 9.238 & 681789 & 0.18 & Bicyclo [2.2.1] heptan-2-ol, 1,7,7-trimethyl- \\
\hline 8 & 9.609 & 1254867 & 0.34 & 3-Cyclohexene-1-methanol, Alpha.4- \\
\hline 9 & 10.199 & 2045877 & 0.55 & 2,3-Dihydro-benzofuran \\
\hline 10 & 10.427 & 12864652 & 3.45 & 4-Phenyl-2-butanone \\
\hline 11 & 10.885 & 1894235 & 0.51 & Cinnamaldehyde, $(\mathrm{E})-$ \\
\hline 12 & 11.041 & 366311 & 0.10 & Bicyclo [2.2.1] heptan-2-ol, 1,7,7-trimethyl- \\
\hline 13 & 11.323 & 628908 & 0.17 & 2-Propenoic acid, 3-phenyl-, methyl ester \\
\hline 14 & 11.497 & 1547664 & 0.42 & 2-Methoxy-4-vinylphenol \\
\hline 15 & 12.343 & 607787 & 0.16 & 4-Epi-cubedol \\
\hline 16 & 12.456 & 5758227 & 1.54 & 2-Propenoic acid, 3-phenyl-, methyl ester, (z) \\
\hline 17 & 12.529 & 947072 & 0.25 & 2-Hepten-3-ol, 4,5-dimethyl- \\
\hline 18 & 12.873 & 1270547 & 0.34 & 2-(1,3-Dithian-2-yl)-1,5,5-trimethyl-3-methyl \\
\hline 19 & 12.963 & 233296 & 0.06 & 1,6-Cyclodecadiene, 1-methyl-5-methylene-8- \\
\hline 20 & 13.031 & 1738968 & 0.47 & 1-Hydroxymethyl-2-methyl-1-cyclohexene \\
\hline 21 & 13.280 & 172140 & 0.05 & 2-Furanmethanethiol, 5-methyl- \\
\hline 22 & 13.325 & 283642 & 0.08 & Cis-.beta. -farnesene \\
\hline 23 & 13.945 & 846456 & 0.23 & Cyclopropane carboxylic acid, 2,2-dimethyl- \\
\hline 24 & 14.709 & 514301 & 0.14 & 1,6,10-Dodecatrien-3-ol, 3,7,11-trimethyl-, (E)- \\
\hline 25 & 14.861 & 1618070 & 0.43 & Cis-Z-.alpha. -bisabolene epoxide \\
\hline 26 & 14.972 & 621474 & 0.17 & 9-Eicosene, $(\mathrm{E})$ - \\
\hline 27 & 15.162 & 455187 & 0.12 & (-)-5-Oxatricyclo $[8 \cdot 2 \cdot 0.0(4,6)]$ dodecane \\
\hline 28 & 15.324 & 5863438 & 1.57 & 3A(1H)-azulenol, 2,3,4,5,8,8a-hexahydro-6, 8A-D \\
\hline 29 & 15.394 & 3973843 & 1.07 & Benzene, 1,2,4-trimethoxy-5-(1-propenyl)-, (z)- \\
\hline 30 & 15.690 & 1617751 & 0.43 & Beta. -D-glucopyranose, 1,6-Anhydro- \\
\hline 31 & 16.166 & 2322736 & 0.62 & 2-Naphthalenemethanol \\
\hline 32 & 16.270 & 608336 & 0.16 & Spiro [4.5] dec-8-en-7-one \\
\hline 33 & 16.957 & 1046848 & 0.28 & Tetradecanoic acid \\
\hline 34 & 17.051 & 2473341 & 0.66 & Tetracyclo $[5,3,1,0 \mathrm{e} 2,6-0 \mathrm{e} 8,11]$ undecan-4-ol, 6- \\
\hline 35 & 17.247 & 1207147 & 0.32 & Cyclohexane, 1,2,3,4,5,6-hexachloro-, (1.alpha) \\
\hline 36 & 17.327 & 982860 & 0.26 & 2(4h)-Benzofuranone, 5,6,7,7a-tetrahydro-6-h \\
\hline 37 & 17.491 & 566590 & 0.15 & 4-Hydroxy-3, 5,5-trimethyl-4-[(1e)-3-oxo-1-bute \\
\hline 38 & 17.688 & 746785 & 0.20 & (Albicanol) decahydro-2-methylene-5, 5,8A-T \\
\hline 39 & 17.755 & 4119627 & 1.10 & 2,6,10-Trimethyl, 14-ethylene-14-pentadecne \\
\hline 40 & 18.014 & 1672465 & 0.45 & 3,7,11,15-Tetramethyl-2-hexadecen-1-ol \\
\hline 41 & 18.206 & 1897125 & 0.51 & 2-Hexadecen-1-ol, 3,7,11,15-tetramethyl-, [R-[R \\
\hline
\end{tabular}


[Khatri et. al., Vol.5 (Iss.2): February, 2017]

ICV (Index Copernicus Value) 2015: 71.21
ISSN- 2350-0530(O), ISSN- 2394-3629(P)

IF: 4.321 (CosmosImpactFactor), 2.532 (I2OR)

InfoBase Index IBI Factor 3.86

\begin{tabular}{|c|c|c|c|c|}
\hline 42 & 18.640 & 2645523 & 0.71 & Hexadecanoic acid, methyl ester \\
\hline 43 & 18.851 & 825470 & 0.22 & Cis-9-Hexadecenoic acid \\
\hline 44 & 19.064 & 21965987 & 5.89 & Pentadecanoic acid \\
\hline 45 & 19.306 & 508895 & 0.14 & Hexadecanoic acid, ethyl ester \\
\hline 46 & 19.401 & 2348651 & 0.63 & Benzene, 1,3-dimethoxy-5-[(1E)-2-phenylethenyl]- \\
\hline 47 & 19.551 & 1307399 & 0.35 & 1-Hydroxy-1, 7-dimethyl-4-isopropyl-2, 7-cyclodecadiene \\
\hline 48 & 19.613 & 709077 & 0.19 & 3-Hydroxy-7-methoxy-3-phenyl-4-chromanone \\
\hline 49 & 20.003 & 1001904 & 0.27 & Heptadecanoic acid \\
\hline 50 & 20.134 & 675976 & 0.18 & Phenol, 2-[2-(4-methoxyphenyl) ethenyl]-, (e)- \\
\hline 51 & 20.201 & 673485 & 0.18 & N-Nonadecanol-1 \\
\hline 52 & 20.313 & 1396296 & 0.37 & 9,12-Octadecadienoic acid ( $\mathrm{z}, \mathrm{z})$-, methyl ester \\
\hline 53 & 20.361 & 1672529 & 0.45 & 9-Octadecenoic acid (Z)-, methyl ester \\
\hline 54 & 20.498 & 3381083 & 0.91 & Phytol \\
\hline 55 & 20.578 & 568527 & 0.15 & Methyl stearate \\
\hline 56 & 20.725 & 6980248 & 1.87 & 9,12-Octadecadienoic acid (z, z)- \\
\hline 57 & 20.768 & 6548079 & 1.76 & 9-Octadecenoic acid \\
\hline 58 & 20.797 & 5362153 & 1.44 & 9,12,15-Octadecatrienoic acid, $(\mathrm{Z}, \mathrm{Z}, \mathrm{Z})$ - \\
\hline 59 & 20.948 & 3431484 & 0.92 & Octadecanoic acid \\
\hline 60 & 21.326 & 247982 & 0.07 & 2,6-Dodecadien-1-ol, 3,7,11-trimethyl-, (E, E)- \\
\hline 61 & 21.842 & 14641181 & 3.93 & Benzene, 1,3-dimethoxy-5-[(1E)-2-phenylethenyl]- \\
\hline 62 & 21.955 & 5366606 & 1.44 & 2-Methyl-3, 5-dinitrophenyl, Beta. -Phenyl propionate \\
\hline 63 & 22.591 & 36220037 & 9.71 & 7-Phenyl-4trans-heptenone-3 \\
\hline 64 & 22.710 & 2963183 & 0.79 & 1,1'-Biphenyl, 2,2'-dimethyl-6, 6'-dinitro- \\
\hline 65 & 22.950 & 1796418 & 0.48 & (1-Benzyl-2-O-tolyl-ethyl)-isonitrile \\
\hline 66 & 23.103 & 3063724 & 0.82 & Benzene, (1-hexylheptyl)- \\
\hline 67 & 23.201 & 10538712 & 2.83 & 3-Heptanone, 5-hydroxy-1, 7-diphenyl- \\
\hline 68 & 23.979 & 18758286 & 5.03 & 3-Heptanone, 5-hydroxy-1, 7-diphenyl- \\
\hline 69 & 24.997 & 2419107 & 0.65 & Cis-10-Nonadecenoic acid, methyl ester \\
\hline 70 & 25.129 & 1727900 & 0.46 & (1-Benzyl-cyclopropyl)-methanol \\
\hline 71 & 25.363 & 15595779 & 4.18 & 4H-1-Benzopyran-4-one \\
\hline 72 & 25.500 & 5818625 & 1.56 & 4,6-Heptadien-3-one, 1,7-diphenyl- \\
\hline 73 & 25.769 & 1215487 & 0.33 & 1-Penten-3-one, 4-methyl-1-phenyl- \\
\hline 74 & 26.700 & 1305692 & 0.35 & 17-Ethynyl-17-hydroxyestr-5 (10)-en-3-one \\
\hline 75 & 27.862 & 9263463 & 2.48 & 1-Penten-3-one, 4-methyl-1-phenyl- \\
\hline 76 & 28.088 & 1341273 & 0.36 & (Albicanol) decahydro-2-methylene-5, 5,8a-t \\
\hline 77 & 29.034 & 2961307 & 0.79 & Coumaran-5, 6-diol-3-one, 2-[4-methoxybenzylidene]- \\
\hline 78 & 29.383 & 1692902 & 0.45 & 4-Pentenoic acid, 2,2-diethyl-3-oxo-5-phenyl-, ethyl ester \\
\hline 79 & 29.868 & 1573072 & 0.42 & Squalene \\
\hline 80 & 29.977 & 1103730 & 0.30 & (Albicanol) decahydro-2-methylene-5, 5,8A-T \\
\hline 81 & 31.584 & 1292488 & 0.35 & Tetramethyl ether of catechin \\
\hline 82 & 31.763 & 5621658 & 1.51 & 2H-1-Benzopyran-6-ol \\
\hline 83 & 32.259 & 2737683 & 0.73 & Tetramethyl ether of catechin \\
\hline 84 & 33.381 & 1420932 & 0.38 & Beta. -Tocopherol \\
\hline 85 & 33.683 & 5784350 & 1.55 & Gamma. -Tocopherol \\
\hline
\end{tabular}




$\begin{array}{lcccll}86 & 35.217 & 1274033 & 0.34 & \text { Cholesterol } & \text { Infor } \\ 87 & 35.447 & 37247907 & 9.99 & \text { Vitamin E } \\ 88 & 37.872 & 1889897 & 0.51 & \text { Ergost-5-en-3-ol, (3.beta.24R)- } \\ 89 & 38.743 & 2735016 & 0.73 & \text { Stigmasterol } \\ 90 & 40.525 & 16941780 & 4.54 & \text { Stigmast-5-en-3-ol, (3.beta.)- }\end{array}$

InfoBase Index IBI Factor 3.86

Table 3: Activity of phyto-components identified in Elettaria cardamomum leaf extract by GCMS

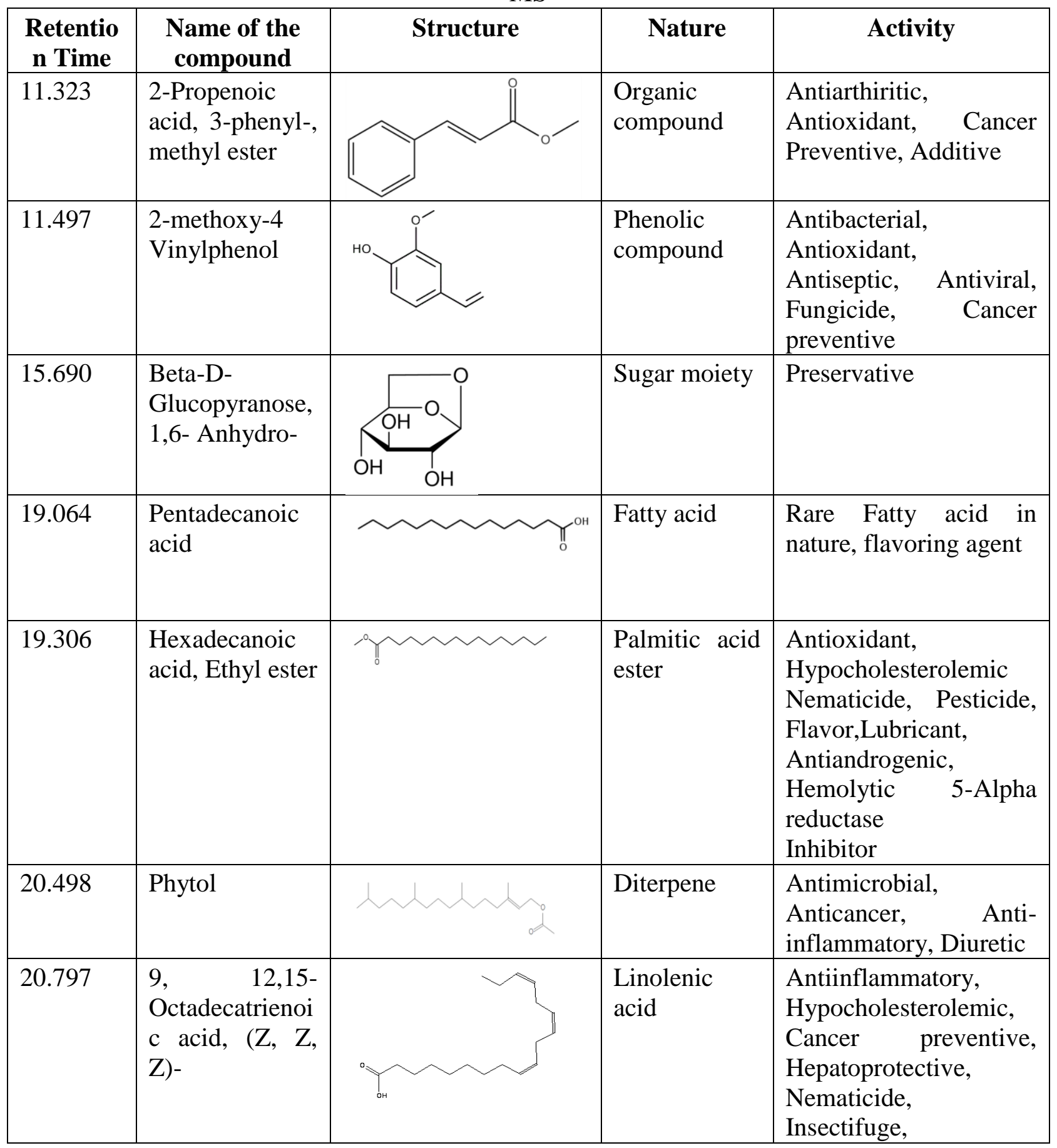




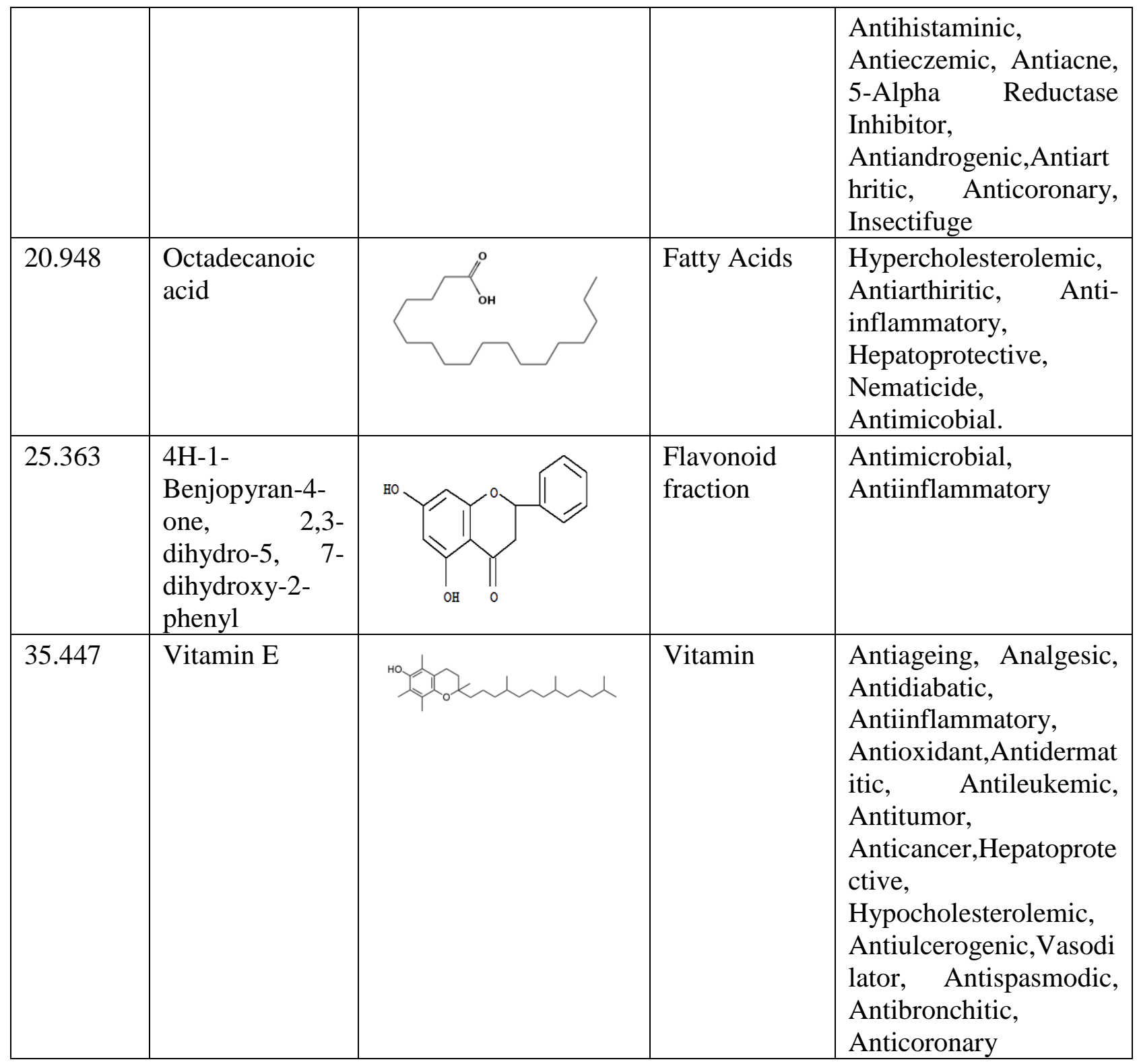

The GC-MS chromatogram of the major compounds detected was shown in (Fig. 1, Table 2 and Table 3). The results revealed that Vitamin E, Pentadecanoic acid, Eucalyptol, Octadecanoic acid, Squalene, stigmast-5-en-3-ol, (3.beta.)-, 4-phenyl-2-butanone, 3-Heptanone, 5-hydroxy-1, 7diphenyl-, 1-Penten-3-one, 4-methyl-1-phenyl-, 4H-1-Benjopyran-4-one, 2, 3-dihydro- 5, 7dihydroxy-2-phenyl are present as one of the major components in the methanol extract and has antioxidant, anticancer, antitumor, antibronchitic, anti-inflammatory activities. The structure and kinetics studies of n-Hexedeconic acid showed that it is an inhibitor of phospholipase, and hence it is an anti-inflammatory compound. Also, GC-MS studies have revealed antiarthiritic, anticancerous, hypocholesterolemic, nematicide, pesticide, lubricant, and antiandrogenic activities that were also reported by (Kumar et al., 2010; Aparna et al., 2012). 
The results of FT-IR analysis confirmed the presence of alcohols, phenols, alkanes, aromatic ring, alkyl halides, ether linkage and alkynes presented in Fig. 2 and Table 4 and in accordance with the results (Mohani et al., 2014; Das et al., 2011).

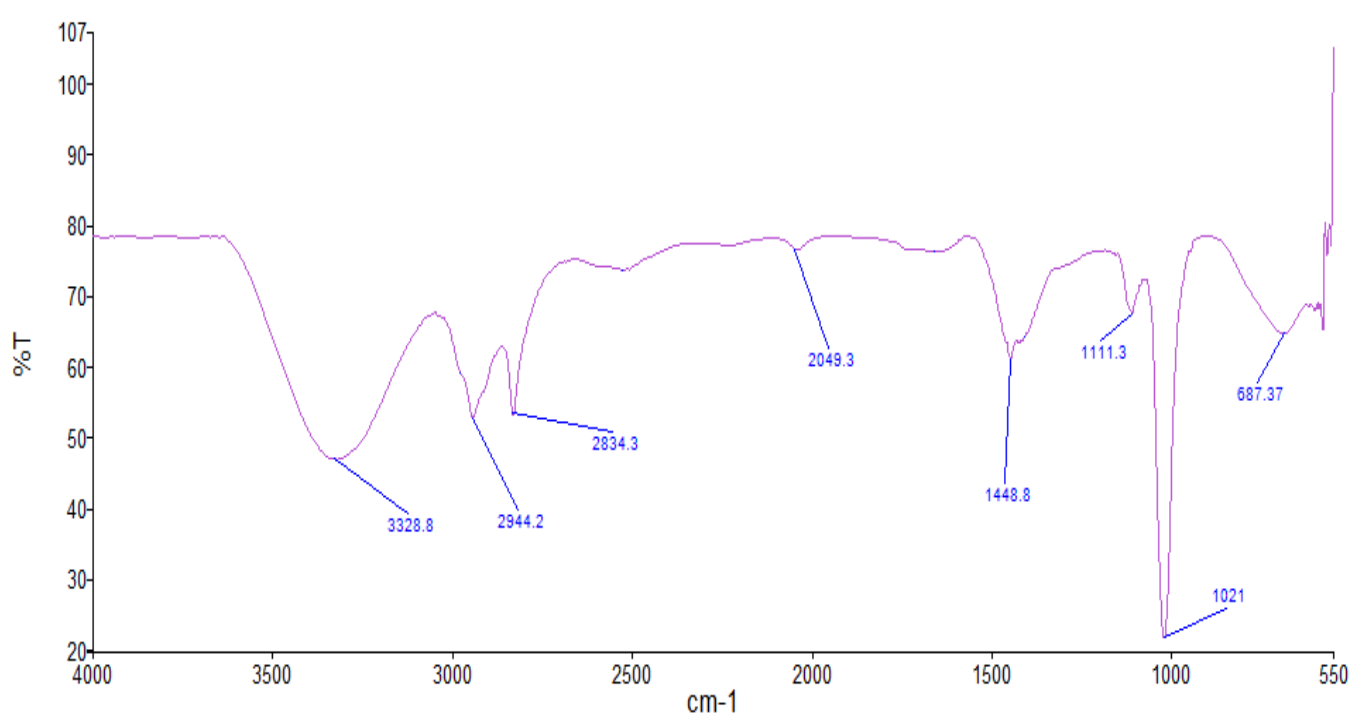

Figure 2: FTIR analysis of leaves of Elettaria cardamomum methanolic extract

Table 4: FTIR peak values of methanolic extract of Elettaria cardamomum leaves

\begin{tabular}{lll}
\hline Characteristic & Bond & Functional Group \\
Absorption $\left(\mathrm{cm}^{-1}\right)$ & &
\end{tabular}

$\begin{array}{lll}3328.8 & \text { O-H stretch, H- bonded } & \text { Alcohols, Phenols } \\ 2944.2 & \text { C-H stretch } & \text { Alkanes } \\ 2834.3 & \text { C-H stretch } & \text { Alkanes } \\ 2049.3 & \mathrm{C} \equiv \mathrm{C} \text { stretch } & \text { Alkynes } \\ 1448.8 & \mathrm{C}=\mathrm{C} \text { stretch } & \text { Aromatic ring } \\ 1111.3 & \mathrm{C}-\mathrm{H} \text { wag }\left(-\mathrm{CH}_{2} \mathrm{X}\right) & \text { Alkyl halides } \\ 1021 & \mathrm{C}-\mathrm{O}-\mathrm{C} \text { stretch } & \text { Ether Linkage } \\ 687.37 & \mathrm{C}-\mathrm{H} \text { stretch } & \text { Alkanes }\end{array}$

The results of the present study have given biochemical nature of biological and pharmacological properties of methanolic extracts and isolated phytoconstituents of Elettaria cardamomum to enrich our knowledge through GC-MS and FTIR analysis.

\section{Conclusion}

In the present study, phytocomponents and their pharmacological activities have been identified from methanolic extract of Elettaria cardamomum (leaves) by GC-MS analysis. Hence, it is the hallmark to phytochemical, biomedical and pharmacognostical fields to carry out research 
activities and drug formulations. It could be concluded that Elettaria cardamomum comprises of various bioactive compounds and acclaimed as a plant of phytopharmaceutical importance. Though, further studies will need to be undertaken to as certain fully its bioactivity, toxicity profile, effect on the environment and agronomic products.

\section{Acknowledgement}

All the authors wish to express their sincere thanks to Ajai Kumar, Advanced Instrumentation Research Facility (AIRF), Jawaharlal Nehru University, and Delhi for GC-MS analysis. Author PJ is thankful to Assured Opportunity for Research Careers (AORC), Department of Science and Technology (DST), New Delhi for awarding INSPIRE fellowship

\section{Conflict of Interest}

The author's declare that they have no conflict of interest.

\section{References}

[1] Agaoglu, S., Dostbil, N. and Alemdar, S. Antimicrobial effect of seed extract of cardamom (Elettarıa cardamomum Maton). YYÜ Vet FakDerg. 16(2), 2005, 99-101.

[2] Anandhi, K. and Ushadevi, T. Analysis of phytochemical constituents and antibacterial activities of Clerodendrum inerme L. against some selected pathogens. Int. J. Biotechnol. Allied Fields.1(7), 2013, 87-393.

[3] Aparna, V., Dileep, K.V., Mandal, P.K., Karthe, P., Sadasivam C. and Haridas, M. Antiinflammatory Properties of n-Hexadeconic acid. Structural Evidence and Kinetic Assessment. Chem. Biol. Drug. Des.80(3), 2012, 434-94.

[4] Azhagumurugan, C. and Rajan, M.K. Effect of leaf extract of Nilakumil, (Gmelina asiatica) against the root knot Nematode (Meloidogyne Incognita). Res. J. Recent Sci.3, 2014, 264-266.

[5] Balaji, K. and Kilimozhi, D. GC-MS analysis of various extracts of Clerodendrum phlomidis leaf. Int. J. Pharm. Pharm. Sci.6 (1), 2014, 226-232.

[6] Bansod, S. and Rai, M. Antifungal activity of essential oils from Indian medicinal plants against human pathogenic Aspergillus fumigatus and A. niger. World. J. Med. Sci. 3(2), 2008, 81-88.

[7] Baytop, T. Türkiye'de Bitkiler ileTedavi. İ.Ü. Yay. No: 3255, EczacilıkFak. No: 40, İstanbul, 1984.

[8] Britto, JD., Sebastian, SR. Biosynthesis Silver Nanoparticles and its Antibacterial Activity against Human Pathogens. Int J Pharm Sci5, 2012, 257-259.

[9] Das, R.K., Gogoi, N. and Bora, U. Green synthesis of gold nanoparticles using Nyctanthes arbortristis flower extract. Bioprocess. Biosyst. Eng. 34, 2011, 615-619.

[10] El-Malti, J., Mountassif, D. and Amarouch, H. Antimicrobial activity of Elettaria cardamomum: Toxicity, biochemical and histological studies. Food. Chem. 104, 2007, 1560-1568.

[11] Hites Roberts, JKM. and Xia, JH. Methods in cell biology, 49: 1995, 245-258.

[12] Jamal, A., Javed, K., Aslama, M. and Jafri, MA. (2006). Gastroprotective effect of cardamom, Elettaria cardamomum Maton. fruits inrats. J. Ethnopharmacol. 103, 2006, 149-153.

[13] Kapoor, LD. Handbook of ayurvedic medicinal plants, CRCPress, Boca Raton, FL, 2000.

[14] Kirtikar, KR., Basu, BD. Indian Medicinal Plants. Indian Press, India, 1918.

[15] Korikontimath, VS., Mulge, R. and Zachariah, JT. Variations in essential oil constituents in high yielding selections of cardamom. J. Plantation. Craps. 27, 1999, 230- 232. 
[16] Kumar, GS., Jayaveera, KN., Ashok Kumar, CK. and Sanjay, UP., Vrushabendra Swamy, B.M. and Kishore Kumar, D.V. Screening of antioxidant activity, total phenolics and GC-MS study of Vitexnegundo. Trop. J. Pharm. Res. 6 (2), 2007, 717-723.

[17] Kumar, PP., Kumaravel, S. and Lalitha, S. Screening of antioxidant activity, total phenolics and GC-MS study of Vitexnegundo. Afr. J. Biochem. Res. 4(7), 2010, 191-195.

[18] Lin, CW, Yu, CW, Wu, SC and Yih, KH. DPPH free-radical scavenging activity, total phenolic contents and chemical composition analysis of forty-two kinds of essential oils. J. Food. Drug. Anal. 17(5), 2009, 386-395.

[19] Mahadkar, S., Valvi, S. and Jadhav, V. Gas Chromatography Mass spectrometry (GC-MS) Analysis of some Bioactive Compounds from five medicinally relevant Wild edible plants. Asian J. Pharm. Clin. Res.6 (1), 2013, 136-139.

[20] Mohani, N., Ahmad, M., Mehjabeen. And Jahan, N. Evaluation of phytoconstituents of three plants Acorus calamus linn. Artemisia absinthium Linn and Bergenia himalaica boriss by FTIR spectroscopic analysis. Pak. J. Pharm. Sci. 27, 2014, 2251-2255.

[21] Nainwal, P., Batsa, R., Singh, A. and Nanda, D. Medicinal plant studies influenced by the Biotechnological methods an updated review. Int. J. Pharm. Biol. Sci. 2(2), 2011, 501-508.

[22] Ronald Hites, A. Handbook of Instrumental Techniques for Analytical Chemistry (Settle, F.A., ed.), Upper Saddle River, NJ, 1997, pp. 609-626.

[23] Sathish, SS., Janakiraman, N. and Johnson, M. Phytochemical analysis of Vitexaltissima L. using UV-VIS, FTIR and GC-MS. Int. J. Pharm. Sci. Drug Res.4 (1), 2012, 56-62.

[24] Sengupta, A., Ghosh, S. and Bhattacharjee, S. Dietary cardamom inhibits the formation of azoxymethane-induced aberrant crypt foci in mice and reduces COX-2 and iNOS expression in the colon. Asian. Pac. J. Cancer. Prev. 6(2), 2005,118-122.

[25] Shankar, M., Lakshmi, T., Ramesh, B., Roopa, D., Ramanarao, DNV. and Niranjan, B.M. Phytochemical investigation and antibacterial activity of hydroalcoholic extract of terminalia bellirica leaf. Asian Journal of Phytomedicine and Clinical Research. Asian J. Phytomed. Clin. Res. 2(1), 2014, 33 - 39.

[26] Singh, G., Kiran, S., Marimuthu, P., Isidorov, V. and Vinogorova, V. Antioxidant and antimicrobial activities of essential oil and various oleoresins of Elettaria cardamomum (seeds and pods). J. Sci. Food. Agric. 88, 2009, 280-289.

[27] Stary, F. The Natural Guide to Medicinal Herb and Plants. Tiger Books International, London,1998.

[28] Sultana, S., Ripa, F.A. and Hamid, K. Comparative antioxidant activity study of some commonly used spices in Bangladesh. Pak. J. Biol. Sci. 13(7), 2010, 340-343.

[29] Venkatesan, D., Karrunakarn, C.M., Selva, S. and Palani Swamy, P.T. Identification of Phytochemical Constituents of Aegle marmelos Responsible for Antimicrobial Activity against Selected Pathogenic Organisms. Ethnobotanical Leaflets. 13, 2009, 1362- 72.

[30] Vijay, T., Rajan, D., Sarumathy, K., Palani, S. and Sakthivel, K. Cardioprotective, antioxidant activities and phytochemical analysis by GC-MS of Gmelina arborea (GA) in Doxorubicininduced myocardial necrosis in Albino rats. Journal of Applied Pharmaceutical Science.1(5), 2011, 198-204.

[31] World Health Organization (WHO). Available from Traditional Medicine: Definitions. http:// www.who.int / medicines/ areas / traditional/ definitions /en/. Accessed October 7, 2016.

*Corresponding author.

E-mail address: poonamkhatri2@gmail.com 